\title{
DOI 10.26886/2414-634X.9(18)2017.6
}

UDC: 355.457:355.23(73)

THE CONTENT OF CURRICULA, FORMS AND METHODS OF VOCATIONAL TRAINING OF SPECIALISTS IN THE FIELD OF THE USA BORDER PROTECTION

\section{T. Tron}

Kyiv National Linguistic University, Ukraine, Kyiv

The article under consideration deals with the issues of the content of curricula in the process of the USA border protection specialists' vocational training. It defines the forms and methods of their training. The article also states the main principles and ways of the USA border security specialists' training plans and programs. It gives a glimpse on the general issues and tendencies, states main peculiarities of modern American vocational training of specialists in the field of border protection.

Key words: curricula, methods, forms, vocational training, border protection.

Тронь Т. В. Зміст навчальних планів та програм, форм та методів підготовки фрахівців у сфрері охорони кордону США/ Київський національний лінгвістичний університет, Україна, Київ

У статті розкрито питання щодо змісту начальних планів та програм у процесі підготовки майбутніх фрахівців у сфрері охорони кордону США. Також подається опис форм та методів здійснення профресійної підготовки американських фрахівців у сфрері охорони кордону. Стаття визначає головні принципи та способи здійснення навчальних програм та планів, передбачених для підготовки фрахівців охорони кордону США. Подано характеристику загальних аспектів та тенденцій, виявлено головні особливості сучасної системи підготовки фрахівців у сфрері охорони кордону США. 
Ключові слова: плани та програми, методи, фрорми, профресійна підготовка, охорона кордону.

Вступ. Різноманітні аспекти професійної підготовки персоналу правоохоронних органів зарубіжних країн, зокрема поліції, привертали увагу низки українських та зарубіжних вчених, науковців, юристів, істориків. Втім, невивченим залишається елемент професійної підготовки агентів Прикордонного патруля США - країни з багаторічним успішним досвідом реформування системи правоохоронних органів та удосконалення професійної підготовки в цілому та агентів Прикордонного патруля зокрема. Разом з тим, результати аналізу наукових праць, у яких розглядаються питання підготовки фрахівців прикордонних відомств закордоном свідчать про те, що досвід США у цій галузі ще недостатньо досліджений як у теоретичному, так i y практичному аспектах.

Ураховуючи нагальність проблеми й недостатній рівень ії вивчення, метою статті $€$ надати характеристику змісту навчальних планів та програм, фрорм та методів підготовки фахівців у сфрері охорони кордону США.

Виклад основного матеріалу. Навчально-виховний процес $€$ невід'ємною частиною процесу навчання, виховання та розвитку. Зміст цього процесу полягає в передачі соціального досвіду викладача тим, кого він навчає, шляхом взаємодії між ними. Цей процес спрямований на задоволення потреб суспільства в освічених особистостях, які здатні вирішувати економічні, виробничі, соціальні, культурні та наукові питання. Базовими елементами у структурі педагогічного процесу виступають навчання та виховання. Кожен з цих елементів, у свою чергу, складається з багатьох взаємопов'язаних процесів. У навчанні виділяють процес викладання - передача знань й процес навчання, у вихованні - процес виховного впливу та самовиховання. Елементами 
педагогічного процесу $€$ цілі та задачі, зміст, методи, засоби, педагогічні умови та результати педагогічного процесу [2].

Провідні тенденції, спрямовані в умовах сьогодення на оновлення світового освітнього простору, такі: 1) орієнтація більшості країн на перехід від елітної до високоякісної освіти для всіх; 2) поглиблення міждержавного співробітництва у галузі освіти, яке залежить від потенціалу національної системи освіти й умов партнерства держави й окремих учасників; 3) збільшення гуманітарного складника у світовій освіті в цілому за рахунок введення наукових і навчальних дисциплін, орієнтованих на людину: політології, психології, соціології, культурології, екології, ергономіки, економіки. 4) значне впровадження нововведень за умов збереження національних традицій, що склалися, та національної ідентичності країн і регіонів.

Сьогодні є чимало трактувань терміну «професійна освіта». Так, наприклад, за С. Гончаренком, професійна освіта - процес і результат профресійного становлення і розвитку особистості, який супроводжується оволодінням знаннями, навичками і вміннями 3 конкретних професій і спеціальностей [1]. Як стверджують А. Коржуєв та В. Попков, професійна освіта - важливий соціально-державний інститут, який виконує функцію підготовки молодого покоління до вирішення в майбутньому професійних завдань у певній сфрері діяльності та передбачає достатньо високий рівень сфрормованості різних умінь і навичок, а також здібності безперервного їх вдосконалення [5].

Характеризуючи про зміст профресійної освіти США, варто зазначити, що їі особливістю є блоковий хараткер. Так, говорячи про елемент професійної освіти - професійну підготовку фахівців охорони кордону США, слід зауважити, що вона має свої етапи здійснення. Загалом професійна підготовка майбутнього фахівця охорони кордони 
США відбувається за такими етапами: підготовочий курс фрізичної підготовки, базова підготовка в Академії (55 дні), стажування після закінчення Академії під нагядом наставника ( близько 2x років), стажування на підрозділах охорони кордону без участі наставника (до 2 років) та курси підвищення кваліфікації (кілька місяців) [6].

Під поняттям форми організації навчання у педагогічній літературі розуміють спеціальну побудову навчального процесу, характер якої зумовлено змістом навчання, прийомами, методами, засобами діяльності суб'єктів і об'єктів навчання. Тобто це - внутрішня організація змісту, яка виступає як процес взаємодії суб'єктів і об'єктів навчання під час роботи над навчальною програмою та матеріалами [7].

Під методом навчання розуміють спосіб організації практичного й теоретичного освоєння дійсності, зумовлений закономірностями розглядуваного об'єкта [4]. До традиційних методів навчання відносять: лекцій, семінари, групові тренінги, інструктажі, стажування.

Форми навчання поділяються на загальні і специфічні. Загальні форми навчання можна класифрікувати за такими ознаками:

- за спрямованістю підготовки - на теоретичну і практичну;

- за організацією тих, хто навчається, - на колективну, групову, індивідуальну;

- за місцем проведення - на класну і польову;

- за місцем у службовому процесі - на навчально-планову, службово-планову, позаслужбову.

Форми навчання характерні для теоретичних, практичних i тренувальних занять, бойових стрільб і пусків ракет, навчань, військових ігор, проведених у ході планових занять. Кожна форма проведення занять передбачає один або декілька методів навчання. 
Говорячи про фоорми, засоби та методи професійної підготовки майбутніх фахівців у галузі охорони США, варто зауважити, що на сьогоднішній день широко використання набув такий вид організації навчання, як особистісне орієнтоване навчання - спосіб організації навчання, в процесі якого забезпечуються всілякий облік можливостей і здібностей учнів і створюються необхідні умови для розвитку їх індивідуальних здібностей [4].

Під час проведення занять 3 фрізичної підготовки приділяється велика увага безпеці курсантів. Варто зауважити, що заняття з фрізичної підготовки включають у себе елементи боротьби та рукопашного бою. Для занять з боротьби постійно застосовуються різноманітні захисні жилети, шоломи, рукавиці та інше. Курсантам, які займаються самостійно, видаються секундоміри, обладнанні радіо, щоб вони могли сповістити про те, що з ним щось трапилось. Біля спортивного залу, вздовж бігової доріжки піднімаються прапорці п'яти кольорів в залежності від температури повітря, вологості та інших погодних умов. Ці прапорці сповіщають викладачів та студентів які фрізичні вправи дозволяється виконувати на відкритому повітрі. Такий підхід дозволяє запобігти перенапруженню курсантів, отриманню теплових та сонячних ударів. Заняття з фрізичної підготовки на базі Академії відбуваються за загальною програмою підготовки співробітників усіх правоохоронних органів США.

Вогнева підготовка $€$ одним із провідних предметів бойової підготовки військ. Мета - навчити військовослужбовця вмілому і якісному використанню високих вогневих можливостей зброї за різних обставин.

На території Академії Прикордонного патруля США знаходяться тири для виконання бойових стрільб, які також включають в себе навчальні класи, склади 3 озброєнням, боєприпасами та 
обмундирування. Стрілецькі тири дозволяють виконувати бойові стрільби в різних умовах, проводити тактичне навчання та тренувати студентів з застосуванням особливих сценаріїв. Стрільба проводиться з усіх видів озброєння, що застосовується у правоохоронних органах США

Говорячи про фрорми та методи підготовки 3 водіння транспортним засобом варто зауважити, що водій - дисциплінована людина, з почуттям відповідальності, яка вміє аналізувати складні ситуації, робити швидкі правильні висновки і, безумовно, впевнено керує своєю машиною. За програмою базової підготовки в Академії Прикордонного патруля США передбачається, що курсанти вже мають первинні навички володіння транспортним засобом, тому в Академії вони лише удосконалюють свої вміння а а також проходять додатковий курс водіння в екстремальних умовах.

Як з'ясувалось у ході дослідження, добір форм та методів професійної підготовки фрахівців охорони кордону США визначається ідеологією практичного використання набутих вмінь та навичок у професійній діяльності й особистісної орієнтованості навчання. У професійній підготовці фахівців охорони кордону США переважає особистісно орієнтований підхід навчання. Так, на перший план виходять практичні заняття, які імітують ситуації реального життя та особливостей служби на кордоні, що дає змогу відпрацювати та «програти» такі сценарії у ході навчання. Окрім практичних занять, курсанти також проходять курс лекцій з теоретичних дисциплін. Для відпрацювання сценаріїв реального життя запрошуються актори, які виконують різні ролі (нелегали, правопорушники, контрабандисти).

Важливим також $€$ аспект й правової підготовки. Правова підготовка організовується 3 метою забезпечення виконання правоохоронцями службових обов'язків, їх соціальної захищеності у 
відповідності з законами та іншими нормативно-правовими актами, формування правової обізнаності, свідомості і правової культури, формування правомірної поведінки. Змістом правової підготовки $є$ вивчення: законів США, міжнародного права, постанов уряду США, інших загальнодержавних правових актів;наказів та директив МНБ ;розпорядчих документів. Для підвищення рівня правової підготовленості майбутніх фахівців у сфері охорону кордону США до здійснення професійної діяльності впроваджуються активні методи навчання

До таких активних методів відносимо ділові ігри та спілкування. Ділові ігри відбуваються за сценарієм, коли майбутні агенти грають ролі затриманих осіб або ж тих, які мали намір перетнути кордон легально та нелегально та ролі агентів для правового вирішення ситуацій. Згідно з навчальним планом в Академії практикують такі форми навчальних занять з правової підготовки: лекційні і практичні заняття. На лекціях подаються основні теоретичні аспекти правової ситсеми США, курс міжнародного права. Закріплення лекційного матеріалу відбувається на практичних заняттях, де курсанти виявляли володіння необхідним обсягом теоретичних знань і нави- ками самостійного опрацювання навчального матеріалу. Мета практичних занять полягала у виробленні й закріпленні вмінь застосовувати їх на практиці.

Для курсантів Академії Прикордонного патруля США важливим є рівень володіння іспанською мовою, оскільки вона безпосередньо пов'язана 3 виконанням їхніх службових обов'язків. Агенти Прикордонного патруля США щоденно користуються іспанською мовою при затримці контрабандистів, нелегалів або ж допомагають та дають консультації громадянам на американо-мексиканському кордоні. Отже, такі та подібні ситуації вимагають ґрунтовних знань іспанської мови. 
3-поміж методів навчання фахової іспанської мови пріоритетним є метод TBL (task-based learning) - метод на основі завдань. Цей метод навчання іноземних мов був винайдений приблизно у 80-х роках XX століття. Головна мета цього методу полягає комунікативних завдань зосередження на виконанні завдання, а не на вивченні та відпрацюванні правил граматики або лексики. Мета такого заняття виконати завдання, використовуючи відповідну мову для ефективного обміну ідеями, а не вивчити певну структуру. Звичайно, для того, щоб успішно виконати завдання, курсанти повинні правильно використовувати мову і обмінюватись своїми ідеями. Таким чином, мова стає інструментом комунікації, націленим на те, щоб допомогти курсантам успішно виконати поставлене завдання. ченої структури для персоналізованої діяльності [3].

Висновки. Отже, Результати проведеного аналізу показали, що для різних аспектів професійної підготовки фрахівців охорони кордону США використовують різні фрорми та методи навчання. Так, наприклад, найбільш ефективними методами правового аспекту професійної підготовки $€$ теоретичні заняття (для вивчення теоретичних правових засад) та практичні (рольові ігри); для фрізичного аспекту професійної підготовки перевагою $€$ практичні фрорми занять ( відпрацювання елементів рукопашного бою, комплексні заняття з витривалості та фрізичної активності); для комунікативної підготовки (іспанська мова) навчання на основі практичних завдань (TBL), рольові ігри, інтенсивні курси; для вогневої підготовки характерні такі форми та методи навчання, як: розповідь, пояснення, показ, самостійна робота та практика під наглядом інструктора; для такого аспекту професійної підготовки як керування транспортним засобом характерними $\epsilon$ заняття-бесіда (теоретично обґрунтовуються засади та принципи 
керування) та практичні форми навчання: водіння під наглядом інструктора та без нього.

\section{תimepamypa:}

1. Гончаренко С. Фундаменталізація профресійної освіти / C. Гончаренко // Ksztalcenie zawodowe: pedagogika i psychologia. - 2006. № $7 .-$ C. 165-175.

2. Давлатиоева А. Ш. Психолого-педагогические особенности организации подготовки кадров органов внут- ренних дел Республики Таджикистан/ А. Ш. Давлатшоева // Вестник Московского университета МВД России. 2013, №8. C. 226-231.

3. Жицька С. А. Підготовка курсантів вищих військових навчальних закладів до профресійно-комунікативної діяльності за допомогою метода комунікативних завдань / C. А. Жицька // Advanced education1 (2014), C. 13-20.

4. Тезаурус методичного працівника. Укладач Демченко В.В. - Рівне: РОІППО, 2012. - 72 с.

5. Коржуев А. В. Традиции и инновации в высшем профрессиональном образовании / А. В. Коржуев, В. А. Попков. - М.: ИНТРА, 2003. - 411 с. - C. 8.

6. Тронь Т. В. Базова підготовка агентів Прикордонного патруля у системі професійної підготовки працівників правоохоронних органів США / Т. В. Тронь / Науковий огляд: журнал / голов. ред. Башнянин Г. І. - 2017 . - № 1 (33). - C. 107-121.

7. Ягупов В. В. Військова дидактика: навч. посіб. / В. В. Ягупов. - К.: ВПЦ «Київський університет», 2000. - 400 с.

\section{References:}


1. Goncherenko S. Fundamentalizatsiya profesiynoï osviti / S. Goncharenko // Ksztalcenie zawodowe: pedagogika i psychologia. - 2006. - № 7. - S. 165-175.

2. Davlatshoeva A. Sh. Psikhologo-pedagogicheskie osobennosti organizatsii podgotovki kadrov organov vnut- rennikh del Respubliki Tadzhikistan/ A. Sh. Davlatshoeva // Vestnik Moskovskogo universiteta MVD Rossii. 2013, №8. S.226-231.

3. Zhitska, S. A. Pidgotovka kursantiv vishchikh viyskovikh navchalnikh zakladiv do profesiyno-komunikativnoï diyalnosti za dopomogoyu metoda komunikativnikh zavdan / S. A. Zhitska // Advanced education1 (2014), S. 13-20.

4. Tezaurus metodichnogo pratsivnika. Ukladach Demchenko V. V. Rivne: ROIPPO, 2012. - 72 s.

5. Korzhuev A. V. Traditsii $i$ innovatsii $v$ vysshem professionalnom obrazovanii / A. V. Korzhuev, V. A. Popkov. - M.: INTRA, 2003. - 411 s. S. 8.

6. Tron T.V. Bazova pidgotovka agentiv Prikordonnogo patrulya u sistemi profesiynoï pidgotovki pratsivnikiv pravookhoronnikh organiv SShA / T.V. Tron / Naukoviy oglyad: zhurnal / golov. red. Bashnyanin G. I. - 2017. - № 1 (33). - S. 107-121.

7. Yagupov V. V. Viyskova didaktika: navch. posib. / V. V. Yagupov. - K.: VPTs «Kïivskiy universitet», 2000. - 400 s. 